\title{
President Trump's Media Strategy as Was Seen in the Press Conference Following the 2nd 2019 U.S.-North Korea Hanoi Summit
}

\author{
Hiromi Sodekawa \\ Aichi Prefectural University, Nagakute, Japan
}

\begin{abstract}
The 2nd U.S.-North Korea Summit between U.S. President Donald Trump and North Korean leader Kim Jong Un was held in Hanoi, Vietnam on February 27 and 28, 2019. However, no agreement was made despite high expectations before the summit. The author of this paper, who was involved in the press conference following the summit as an interpreter for a Japanese TV program in Tokyo, recognized that Trump, who often criticizes some media outlets, calling them "fake news", handled the press respectfully. To answer the question why there is a gap between his attitudes toward various media outlets, this paper examines the interactions between the president and all 21 reporters who were allowed to ask him questions during the Hanoi press conference, focusing on their questions, the organizations they belonged to, and some personal details. President Trump's extremely well-calculated media strategy is then revealed.
\end{abstract}

Keywords: North Korea, denuclearization, sanctions, media strategy, liberal, pro-Trump

\section{Introduction}

The 2nd U.S.-North Korea Summit between U.S. President Donald Trump and North Korean leader Kim Jong Un was held in Hanoi, Vietnam on February 27 and 28, 2019. However, it broke down without any agreement, although the denuclearization ${ }^{1}$ of North Korea, a declaration of the end of Korean War, and a conclusion of the peace treaty had been highly anticipated before the summit.

The U.S. wanted North Korea to completely dismantle all nuclear facilities in the country in exchange for the lifting of sanctions, whereas North Korea wanted all sanctions to be lifted for just giving up some of their nuclear facilities. They could not meet halfway. President Trump eventually walked out, although both sides confirmed their diplomatic engagement would continue.

The author of this paper undertook simultaneous interpreting on the TV broadcast of the conference aired by a private television station in Japan. In the press room Trump did not look as energetic and spirited as usual,

\footnotetext{
Hiromi Sodekawa, MA (University of British Columbia, Canada), Associate Professor, Aichi Prefectural University, Nagakute, Japan.

1 What denuclearization means is different, depending on whether it refers to North Korea only or the whole Korean Peninsula, including South Korea. The denuclearization of North Korea means ceasing nuclear development in North Korea and targeting North Korean nuclear activities. The denuclearization of the Korean Peninsula covers not just North Korean nuclear activities, but a complete withdrawal of US forces stationed in South Korea, which possesses nuclear arms, from the Korean Peninsula. Basically, in its definition, it means the former for the US, while the latter for North Korea. In the process of negotiation, we witness some delicate changes of the definition about what extent the denuclearization covers.
} 
but he handled the press with respect. Usually, President Trump lashes out at some news networks as producers of "fake news". He does not listen to any criticism about himself or his administration from, for example, CNN and the New York Times. This paper reflects on why there was such a gap between Trump's rather decent attitude in the Hanoi press conference and his hostility during other press conferences.

This paper also examines all 21 reporters who were allowed to ask questions of the president during the 38-minute Hanoi conference ${ }^{2}$, focusing on their questions, the organizations they belonged to, and some personal details such as attire. This paper then reveals elements of President Trump's extremely well-calculated media strategy.

\section{What Types of Reporters Were Called on in the Press Conference?}

Reporters sometimes did not offer their names or spoke too softly to be heard. But by observing them in the video or undertaking background research, they have been identified as much as possible. A summary of the $\mathrm{Q} \& \mathrm{~A}$ is described below:

1. $\left(04^{\prime} 31^{\prime \prime}\right)^{3}$ Major Elliott Garret, Chief White House Correspondent, Correspondent for CBS News, and a Correspondent at Large with the National Journal. CBS is considered liberal.

Q: Has this process been more difficult than you thought? Was the North Korean demand for lifting of some sanctions the real sticking point? Will there be a third summit? Will all the sanctions in existence remain?

A: North Korea was willing to denuke a large area, but they wanted the sanctions lifted in their entirety, and we couldn't do that. We had to walk away from that. The sanctions are in place. We haven't given up anything. They have tremendous potential.

2. (05’49) John David Roberts, Canadian-born TV journalist, Fox News Channel, Chief White House Correspondent. He used to work for CBS News and CNN. Fox News is conservative and pro-Republican. It is unequivocally pro-Trump. Brian Ott, a scholar of communication studies, says Fox "effectively functions as state-sponsored television for the Trump administration" (2019).

Q: Is there any distance toward Kim's vision of denuclearization? He wants to keep some nuke, but would you allow him to do that? How can you bridge that gap between now and the next time?

A: We did some distance. I don't want to comment on their keeping nukes.

Trump suddenly interrupted Roberts rather abruptly and turned to Sean Hannity of Fox News.

3. (06’38) Sean Patrick Hannity, an American talk shows host and conservative political commentator. Hannity hosts a commentary TV program, Hannity, and a national syndicated talk radio show, The Sean Hannity Show, on Fox News.

Trump: There is a gentleman nobody has ever heard of. Sean Hannity—what are you doing here, Sean Hannity? Should we let him do a question? I don't know.

Roberts is also a reporter of Fox News, but Hannity is a particularly well-known Trump enthusiast, calling himself "an advocacy journalist or an opinion journalist" in a 2017 NY Times interview so that he is no longer a journalist in its true sense, as he has dispensed with all commitment to objectivity. White house advisors characterize him as the "shadow chief-of-staff" (Wemple, 2019).

In the middle of the interaction with Roberts, Trump suddenly turned his attention to Hannity. This was quite discourteous to Roberts, even though both reporters belong to the pro-Republican Fox News. It seemed as if Trump wanted to avoid Roberts' tenacious questioning about whether he would accept North Korea retaining

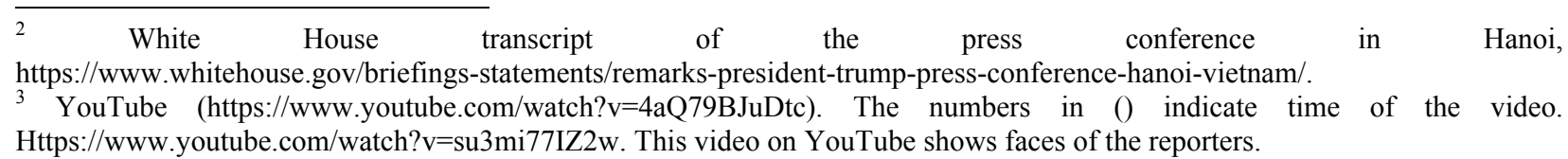


some nukes. Trump probably sent a signal to Roberts that his line of questioning had gone too far. Furthermore, internal conflicts or divisions at Fox News were reported between those most loyal to Trump and those less so (Barber, 2019).

On the other hand, how Trump referred to Hannity might also sound uncivil. His comments were playful, but could be seen as being passive-aggressive. Hannity was expected to have an exclusive interview with Trump in the wake of a successful Hanoi summit. So, Trump might have taken out some frustration on him, who was anyway a fervent supporter.

Besides this, the relationship between Trump and Fox News does not always work out well. According to L'Agence France Presse (AFP) on August 29, 2019, Trump complained that the favorable Fox News was not "working for us anymore". There might have been some precursory incidents already happening at the time of the Hanoi conference.

After this interruption, Roberts could not maintain his engagement with the president. Trump did not answer the question about how he could bridge the gap between then and the next time, and he simply said, "With time. It'll be bridged. We have to have sanctions".

(07'28) Sean Hannity

Q: President Reagan walked away in Reykjavik (US President Ronald Reagan and General Secretary of the Communist Party of the Soviet Union Mikhail Gorbachev held a summit meeting in 1986, which collapsed. But this eventually resulted in the treaty). A lot of condemnation at the time. It ended up working out very well for the United States (INF (Intermediate-Range Nuclear Forces) Treaty concluded in 1987). Was this walkout your decision? What message would you send Chairman Kim, as he's listening to this conference?

A: I don't want to say it was my decision. I want to keep the relationship. We got our hostages back. Chairman Kim promised me is, he's not going to do testing of rockets and nuclear. I trust him, and I take him at his word. We'll be talking.

Hannity did not give his name, beginning by saying, "I work in radio and TV. Mr. President, thank you. Mr. Secretary, good to see you". This sounded a little awkward. He seemed bewildered with how to respond to Trump. Still, he compared Trump to popular president Ronald Reagan, and his remarks that the once broken-down negotiation had been eventually working well for the US were to boost Trump. This indeed demonstrates he is truly a Trump supporter. CNN reporter Jim Acosta commented that Hannity "lobbed softball questions" (2019).

4. (09'15) Jonathan Karl, ABC News Chief White House Correspondent, 94th President of the White House Correspondents' Association. ABC News leans liberal, center left.

Q: Did you learn anything new about Chairman Kim? While this was going on, the drama back in Washington. What's your response to your former lawyer, Michael Cohen?

A: It's incorrect. Having a fake hearing like that, and having it in the middle of this very important summit is really terrible. He lied a lot, but he didn't lie about one thing. He said no collusion with the Russian hoax. He could've gone all out. He only went about 95 percent instead of 100 percent. I call this whole hoax the Russian witch hunt.

In Washington, a congressional testimony was held in parallel with the Hanoi summit. Michaele Cohen, who worked for Trump for 10 years as a lawyer and fixer, testified about a hush payment to women who had allegedly had sexual relations with Trump, and alleged Russian collusion in the 2016 presidential election. Cohen called Trump "a liar, a con man, a racist"

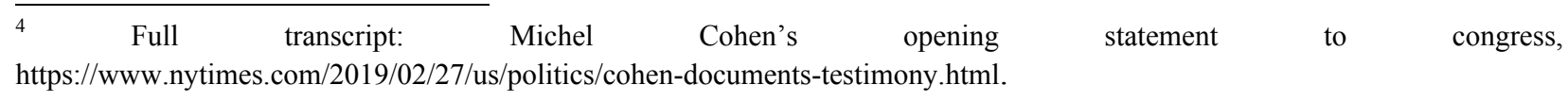


who in fact paid little attention to the summit. Trump apparently kept an anxious eye on it. The author was given a briefing by a TV producer on Cohen's testimony, "there gonna be lots of questions on his testimony".

Trump looked very well prepared for those questions. He picked up one phrase only "no collusion" from among Cohen's many words. In the end, Karl was the only reporter, who asked about the testimony. So, Trump's strategy on this issue was successful at that time.

But let it be clear. Cohen did not say there was "no collusion". What he said was that he did "not know of direct evidence that Mr. Trump or his campaign colluded with Russia".

5. (11'34) Jane Tung (sp), Guangdong Television, a young, female Asian reporter, wearing a white jacket with a red top. Trump called on her, instead of another woman who was already holding a mic. He seemingly showed off, implying "I am the one who is in control here".

Q: What was the atmosphere like when you walked away from the negotiation table?

A: It was very good, very friendly. This been solved during many presidential runs. They did nothing. It's [North Korea] a totally different system. But we like each other.

Trump let Secretary of State, Pompeo, speak and support him.

6. (13’30) Jon Sopel, BBC North America Editor. BBC News leans liberal, center left.

Q: Was it premature to have held the summit? In the White House schedule last night, it said signing agreement today. I wonder whether you could sketch out what the next few months look like.

A: You always have to be prepared to walk. I could've signed an agreement today. But it just wasn't appropriate. I want to do it right. I'd much rather do it right than do it fast.

Trump and Sopel had several strained arguments before, including a press conference on February 16, 2017 when they jabbed at each other about the BBC's principles. When Sopel mentioned his name and the BBC, Trump said, "Here's another beauty". "Good line. Impartial, free and fair", said Sopel. "Just like CNN", said Trump, comparing it to CNN which he always calls "Fake news".

Trump knows Sopel well. But in the Hanoi conference, he simply said, "Go ahead. In the back". Sopel did not give his name or which outlet he worked for and jumped right into his question. The reason why Sopel was given a chance to speak is probably that the $\mathrm{BBC}$ is a world-renowned British media corporation. No CNN reporters were called on that day.

7. (14'25) A female South Korean reporter. She did not give her name. Looked less experienced and tried hard to ask questions.

Q: I appreciate your effort to advance denuclearization in Korean Peninsula. Could you elaborate on the options and the various ways to do that?

A: We discussed many ways. [The denuclearization means] to get rid of the nukes. There is tremendous potential in North Korea. It's going to be an absolute economic power.

Trump did not say any more.

8. (15'29) David Sanger, national security correspondent, the New York Times. A 36-year career in the NY Times, which is considered liberal left.

Q: Since the 1st summit in Singapore, you have seen Chairman Kim increase the number of missiles he's produced and continue to produce more nuclear material. That's been a pressure point on you.

A: Some people are saying that, and some people are denying that. I could've taken that out today, but you and others would've said we didn't get enough for what we'd be giving up. We have a whole big partnership with the United Nations and many countries, including Russia, China, and of course, South and Japan. I don't want to do something that is going to violate the trust that we've built up. 
North Korea would denuclearize only the Nyeongbyeon complex in exchange for lifting all the sanctions, which was not what the US wanted.

Pompeo supported Trumps' remarks.

9. (18'36) A young, female, seemingly South Asian reporter with a red jacket. She did not give her name.

Q: Would you willing to give up all of the sanctions, when North Korea gives up everything to do complete, verifiable denuclearization?

A: It's a good question. I don't want to say that to you from the standpoint of negotiation. Many other countries, Japan, South Korea, are going to be helping.

Trump interrupted the reporter's questions twice. He also made a compliment on her rather plain question: "It's a good question". This remark itself could be interpreted as him treating her as being insignificant, because if North Korea gives up everything, it is highly possible that the US will give up the sanctions.

10. (20’00) Jessica Stone, CGTN (China Global Television Network). This is an international news channel of Chinese state TV, CCTV. A young, white woman in a red one-piece dress.

Q: You talk about China being willing, potentially, to help economically. How would you describe China's role in facilitating the engagement between Pyongyang and Washington?

A: China has been a big help. 93 percent of the goods coming into North Korea come through China. China has an influence. And Russia has been a big help too.

11. (21’09) Jen Chen, Shenzhen Media Group of China. A young, female reporter wearing a deep-pink jacket. She hardly looked up from the notebook she was holding.

Q: In your meeting with Chairman Kim, did the topic of China come up? What would you like accomplish with your agenda regarding China at the next meeting with President Xi Jinping?

A: We did talk about China a lot. Our economy is incredible. Fiat Chrysler just announced that they're going to spend $\$ 4.5$ billion to build a plant in Michigan. With China, they're having some difficulty. To resolve trade deficits and tariff issues, we're putting a tremendous amount of money. Many Presidents should have done this before me, and nobody did.

Trump bragged about the "incredible" performance of the American economy. He talked about the US-China trade conflicts. But here too, he did not answer the question directly.

Statistics $^{5}$ show the US trade deficit with China was 345.6 billion dollars in 2019, 17.6\% down from 419.5 billion dollars in 2018. But the US total trade deficit had not gone down, because the US was importing more from other countries to make up for the decreased imports from China.

12. (23'34) Chad O'Carrol, NK (North Korea) News. He is Irish, a founder and CEO of Korea Risk Group, and a journalist and researcher of North Korea.

Q: What's your message for President Moon, who has effectively reached the glass ceiling, as far as inter-Korean cooperation is concerned? What's next for U.S.-ROK military drills?

A: I like President Moon very much. We have a great relationship. I have a great relationship with almost every leader. Maybe it sort of freezes them up a little bit. We'll be calling President Moon very soon. And he'll be one of the first calls. I'll be calling Prime Minister Abe of Japan.

From around the 9th reporter on, when Trump was pretty much finished with the mainstream news media, it became evident that he said whatever he wanted to say rather than answering the actual questions.

13. (24’41) A young, male Chinese reporter from the Global Times China. His name sounded like Yan Sang (sp), but inaudible.

Q: What are you expecting China to do in the next step to mediate your relationship with North Korea?

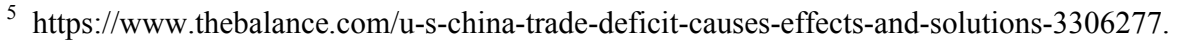


A: China has been very helpful. President Xi is a great leader. He's a highly respected leader all over the world.

Trump did not mention the next step and asked Pompeo to take over.

14. (25'33) A young, female white reporter. She did not give her name. Her English was a little hard to understand. She kept looking at her notes.

Q: Did you commit with Chairman Kim to a next summit? Do you accept North Korea as a nuclear-armed state for the time being? Are you thinking about re-imposing the military exercises with South Korea, or will you keep it a freeze-for-freeze?

A: It costs us $\$ 100$ million every time we do it. A certain general said, "We fly them in from Guam. It's right next door". Right next door is seven hours away. They come and drop millions of dollars of bombs. We're protecting South Korea. They should help us with that. Those exercises are very expensive. Exercising is fun and they play the war games. And I'm not saying it's not necessary.

We're spending a tremendous amount of money on many countries, protecting countries that are very rich that can certainly afford to pay us. We've picked up over a $\$ 100$ billion just in NATO over the last two years. You'll be seeing that a lot.

However, Trump did not answer the most important question, whether or not he would accept North Korea as a nuclear power.

15. (27'50) A male Asian reporter. He did not give his name. Fluent in English.

He asked about a young American man, Otto Warmbier, who was a symbol of North Korea's violations of the human rights of Americans. He was detained during a trip to North Korea and returned home in 2017 in a deep coma due to brain damage. A few days later he passed away.

Q: Have you, in Singapore or here, confronted Kim Jong Un about Otto Warmbier's death, and asked him to take responsibility? Why do you call him your friend?

A: We have talked about it. I really don't think it was in his interest at all. I know the Warmbier family very well. Really bad things happened to Otto.

Trump kept saying that Kim did not know about it and defended him, and changed the subject to the prisoners and hostages back home. Trump was very boastful of that.

16. (29’54) A young, female Russian reporter from the Sputnik News Agency (formerly Russian Voice). It is under the umbrella of Russian state media outlet, Russia Today. This reporter wore a shoulder-strap one-piece dress with her shoulders exposed.

She asked if Trump had discussed the issue of possible inspections of North Korea's nuclear sites, but he did not understand the question because of her accent of "inspections". Pompeo helped him.

A: We'd be able to do that very easily. The inspections on North Korea will take place. There are sites that people don't know about that we know about.

17. (31'16) A young female reporter from Kann News Israel, an Israeli state broadcasting corporation. She wore a white knit cardigan. She attentively looked at her smartphone.

Q: Following this engagement with North Korea, you are trying to bring peace to the Middle East. Will it require Israel to make compromises to the Palestinians? Prime Minister Netanyahu is about to be indicted today with corruption allegations. Do you wish to tell him something on this occasion?

A: He's been a great prime minister. I don't know about his difficulty. His military has been built up a lot. They buy a lot of equipment from the United States. We give them 4 billion dollar subsidy each year.

We were paying the Palestinians a lot of money. I ended that about two years ago. The toughest of all deals would be peace between Israel and Palestinians. I'd love to be able to produce it.

Both Trump and the reporter deviated from the North Korean issue.

18. (33’25) A young Chinese man. He only said he was from China, not mentioning his name or organization. He looked nervous and talked fast. Trump asked him to repeat his question. 
Q: Do you still believe it is possible that the North Korea and U.S. relation could be like the U.S. and the Vietnam relation in the future?

Trump said first, "We have very, very good relations" and brought up the trade talks with Japan. Did he hear wrong and think that the reporter asked about Japan, not Vietnam, or deliberately ignore Vietnam to talk about Japan? Not sure. Up to this point, Trump had valued Japan and its Prime Minister Abe highly, whenever mentioned. However, he developed his arguments against Japan here, pointing out Japanese car exports to the US, and the US trade deficit with Japan. In this way, he kept Japan in check.

19. (34'24) A young male reporter from Shanghai Media Group. His name was inaudible. This group together with Radio and Television Station of Shanghai represents one of China's largest media and cultural conglomerates.

Q: Do you think the next meeting could be soon, or might take some time?

A: It might not be for a long time. I could've done a deal today, but it would've been something that I wouldn't have been happy about. We just felt it wasn't appropriate.

20. (35'03) Debi Edward, ITV News. She is a veteran female reporter of Asia in ITV news programs. ITV stands for Independent Television, the largest and oldest private broadcasting corporation in the UK.

Q: At which point did it become clear to you that you wouldn't be getting a deal here in Hanoi? The language from yourself and Kim Jong Un was very positive last night and even this morning.

A: The language has been good even now. We became very friendly. This was something that should've been handled by other Presidents long before me. I'm not just blaming the Obama administration, which, by the way, it did nothing.

Again, Trump did not answer the question and blamed previous administrations, particularly the Obama administration, for not handling this issue.

21. (36'20) A young female reporter from Channel A, a South Korean media outlet. She wore a white jacket, and her voice was too soft to catch.

Q: You said that we do not particularly know when North Korean leader will be willing to come to the table and take the actions that's been required. Would the U.S. be willing to strengthen the sanctions and perhaps put the pressure on North Korea to move forward?

A: I don't want to comment on that. We have very strong sanctions. I don't want to talk about increasing sanctions. My whole attitude changed a lot because I got to know Chairman Kim very well. I am thinking of South Korea, Japan, and frankly, of China. President Xi does not want to have a nuclear state right next to China. He would like to see that problem solved, too.

With this remark, the press conference ended. He said, he would "fly back to a wonderful place called Washington, D.C.". He used the word "wonderful" in a cynical way, because he would be back in the middle of the turmoil caused by Cohen's testimony in Washington.

\section{Trump's Media Strategy}

The reporters' organizations and their various features are listed below. Their numbers indicate the speaking order.

As the table shows, Trump called on big-name reporters of the western mainstream media, whom he knew well, at the early stage of the press conference. They included both conservative pro-government reporters and liberal left-wingers. But he chose two reporters from Fox News particularly at the earliest time. He might have wanted them to show their support quickly, believing that they would not blame him for the collapse of the negotiations. Certainly, one of them gave a praise to him immaturely, while the summit had yet to achieve something. 


\begin{tabular}{|c|c|c|c|c|c|c|}
\hline $\begin{array}{l}\text { US } \\
\text { Liberal } \\
\text { Center- } \\
\text { left } \\
\end{array}$ & $\begin{array}{l}1 \mathrm{CBS} \\
\text { Male }\end{array}$ & $\begin{array}{l}8 \text { New York } \\
\text { Times } \\
\text { Male }\end{array}$ & $\begin{array}{l}4 \mathrm{ABC} \\
\text { Male }\end{array}$ & & & \\
\hline $\begin{array}{l}\text { UK } \\
\text { Liberal } \\
\text { Center- } \\
\text { left }\end{array}$ & $\begin{array}{l}6 \text { BBC } \\
\text { Male }\end{array}$ & $\begin{array}{l}20 \text { ITV } \\
\text { Veteran } \\
\text { Female reporter }\end{array}$ & & & & \\
\hline $\begin{array}{l}\text { US } \\
\text { Conservative } \\
\text { Right }\end{array}$ & $\begin{array}{l}2 \text { Fox } \\
\text { Male }\end{array}$ & $\begin{array}{l}3 \text { Fox } \\
\text { Male }\end{array}$ & & & & \\
\hline $\begin{array}{l}\text { China } \\
\text { State- } \\
\text { sponsored } \\
\text { media }\end{array}$ & $\begin{array}{l}5 \text { Guangdong } \\
\text { TV } \\
\text { Young female } \\
\text { White jacket with } \\
\text { red inner }\end{array}$ & $\begin{array}{l}10 \text { CGTN } \\
\text { Young female } \\
\text { Red one-piece } \\
\text { dress }\end{array}$ & $\begin{array}{l}11 \text { Shenzhen } \\
\text { Media Group } \\
\text { Young female } \\
\text { Deep pink jacket }\end{array}$ & $\begin{array}{l}13 \text { Global Times } \\
\text { China } \\
\text { Young male }\end{array}$ & $\begin{array}{l}18 \\
\text { Young male } \\
\text { Chinese }\end{array}$ & $\begin{array}{l}19 \\
\text { Shanghai Media } \\
\text { Group } \\
\text { Young male }\end{array}$ \\
\hline South Korea & $\begin{array}{l}7 \\
\text { South Korea } \\
\text { Young female }\end{array}$ & $\begin{array}{l}21 \text { Channel A } \\
\text { Pay TV Network } \\
\text { Young female } \\
\text { South Korean } \\
\text { White jacket }\end{array}$ & & & & \\
\hline Asian & $\begin{array}{l}9 \\
\text { Young female } \\
\text { Asian } \\
\text { Red jacket }\end{array}$ & $\begin{array}{l}15 \\
\text { Young male } \\
\text { Asian }\end{array}$ & & & & \\
\hline $\begin{array}{l}\text { North } \\
\text { Korea } \\
\text { Lean? }\end{array}$ & $\begin{array}{l}12 \text { North Korea } \\
\text { News } \\
\text { male } \\
\text { Irish } \\
\end{array}$ & & & & & \\
\hline $\begin{array}{l}\text { Russia } \\
\text { State } \\
\text { news } \\
\text { agency }\end{array}$ & $\begin{array}{l}16 \text { Sputnik } \\
\text { Agency } \\
\text { Young white } \\
\text { female } \\
\text { Shoulder-strap } \\
\text { one-piece dress }\end{array}$ & & & & & \\
\hline $\begin{array}{l}\text { Israel } \\
\text { Public } \\
\text { broad- } \\
\text { casting } \\
\text { corp. } \\
\end{array}$ & $\begin{array}{l}17 \text { Kann News } \\
\text { Israel } \\
\text { Young female } \\
\text { White knit outfit }\end{array}$ & & & & & \\
\hline Other & $\begin{array}{l}14 \\
\text { Young white } \\
\text { female }\end{array}$ & & & & & \\
\hline
\end{tabular}

As for the liberal left-wingers, Trump excluded CNN as usual, which he claims as fake news. But he caked on other liberal reporters, who were also likely to ask tricky questions. He might have wanted to finish quickly with this group of reporters.

Notably, young reporters from the Chinese media were given opportunities to speak. At least six were called. Chinese media outlets are state-sponsored, not privately owned free press. South Korean and other Asian reporters were conspicuous as well. A reporter from a Russian state news agency and an Israeli reporter spoke. This suggests that Trump intentionally chose state-controlled media and inexperienced looking, young Asian reporters, particularly women.

This tendency was described by CNN reporter Jim Acosta: "President Donald Trump showed remarkable deference to reporters from authoritarian governments at last week's failed summit with North Korean leader 
Kim Jon Un. The president spent a share of Thursday's press conference calling on reporters from countries with state-run media, rather than on journalists from free-press nations" (2019).

Acosta had clashed with Trump before. From Trump's perspective, therefore, it was probably taken for granted that Acosta would not be called in this press conference.

Other factors reveal Trump's media tactics. They had already been visible as a prelude to the press conference. For example, White House correspondents were excluded from the hotel's filing center at the arrival of Chairman Kim Jong Un. Four reporters from American media outlets were kept out of the dinner party for Trump and Kim on the previous night.

In addition, only reporters selected by lottery were admitted into the hall of the press conference after they first of all had to apply for admission to the conference, because the White House said the capacity of the hall was limited. In such a way, Trump could control media access.

Therefore, Acosta's other comment, "this was a big debacle for this White House press shop from start to finish", is even more convincing. Trump's media strategy can be seen as extremely successful in that only one reporter asked about Cohen' bombshell testimony.

Trump's selection of young, seemingly inexperienced, female reporters is also worth some analysis. The analysis on gender, age, and outfit styles and colors suggests that Trump made, what he might have considered, safer picks, probably believing that they would not ask difficult questions and he would not have to answer them if he did not want to. Thus, his carefully calculated media strategy is further revealed.

Focusing on the female reporters' choice of attire, it might be possible to understand their intentions or tactics for the press conference. Three out of ten wore reddish jackets or once-piece dresses or tops. Three wore white ones. One woman wore a shoulder-strap one-piece dress, which is unusual for a professional press conference. Why would professional women concern themselves with color or exposed skin? It could be argued that they had a strategy of their own, simply to catch the president's attention. It worked well here.

As for the color red, they remind us of Helen Thomas (1920-2013), a White House correspondent from the United Press International. Thomas was well known for tough questioning of presidents from John F. Kennedy through Barack Obama. She was highly respected, as seen by her front-row seat in the White House briefing room, asking opening and closing questions to presidents. Her signature dress was red. We cannot be sure, but the female reporters in the Hanoi conference might very well have been following Helen Thomas's example.

One other issue should be raised here, which may not be directly related to Trump's media strategy, but worth discussing. This is regarding the Japanese reporters. They did not ask any questions at all at the two press conferences following the 1st and 2nd US-North Korea summits. Even Japan's most concerning issue of abduction, in which Japanese people were abducted by North Korea, was raised by a reporter from other country in the 1st press conference. The author thought at that time that there were no Japanese reporters in attendance.

This issue was touched on in The Economist Front Covers: Effective Communicators III (Sodekawa, 2018), in which journalist and scholar, Takero Nagoshi, expressed grave concerns about the Japanese reporters' poor performance. They missed important opportunities to speak. In fact, one of the Japanese reporters, Akiko Suzuki of the Asahi Shimbun, wrote about it in her 2019 article with both regrets and reflections. She said that 
Asian reporters, other than the Japanese, were full of gumption, standing and shouting out their countries' names to catch the attention of the president.

During the conference, Japanese reporters could not show their presence to the world media and audience. This is certainly a big disadvantage for Japan. So, without being brought under Trump's media control, Japanese media should make their voices heard next time.

To sum up, since the failed 2nd US-North Korea summit, the move towards denuclearization and a peace treaty has not progressed. Trump sometimes criticized South Korea, a US ally, but he downplayed the recent North Korean missile tests. This is probably because Trump was "keen to hold up his engagement with North Korea as a foreign policy success ahead of his 2020 reelection bid" (Reuters 2019). One of the promising examples was the 3rd summit which was held briefly in the demilitarized zone (DMZ) between South Korea and North Korea in June 2019. But progress was not made overall. The deadlock continued.

By March 2020, however, the momentum had dramatically changed. This was because, very importantly, the novel coronavirus broke out and was affecting the world over. The COVID-19 virus will definitely be a key to the politics in every country of the world, including the US ${ }^{6}$.

As references, a list of events after the $2^{\text {nd }}$ summit is noted below:

- North Korea launched two short-range projectiles off its east coast in October, 2019, its first such tests since November 29, 2017 when an ICBM intercontinental ballistic missile was launched. North Korea was frustrated to prod the United States to get back to serious negotiations over its weapons program to relieve sanctions.

- John Bolton, the then national security advisor, gave a harsh criticism on North Korea for violating UN Security Council resolution.

- Trump sent an unexpected "love call" to Kim to see him during his visit to South Korea after attending the G20 in Osaka. Their symbolic meeting was held in the DMZ in June 2019. Trump shook hands with Kim on the North Korean side of the DMZ before crossing, becoming the first US leader to meet his North Korean counterpart at the border. Amid the theater, the leaders held a 50-minute talk, agreeing to set up negotiation teams. This was their 3rd summit, but since then no real working-level negotiations have taken place.

- In the 2018 Singapore meeting, Trump said that he wanted to halt the US's joint military exercise with South Korea, for it is a tremendously expensive war game. Further annual exercises were scrapped. But they resumed scaled-back joint military drills on August 5, 2019. To strongly oppose it, North Korea fired test missiles. Trump still downplayed North Korea's actions, saying their projectiles were not long-range missiles. That is, they would not reach the US.

- South Korea decided to pull out of an intelligence-sharing deal with the General Security of Military Information Agreement (GSOMIA). This worsened the already bad relationship between South Korea and Japan. Trump, frustrated with their months-long feud, criticized South Korean president Moon Jae In and his government for their decision to withdraw from GSOMIA at a G7 meeting in France. All the leaders at the summit were said to be dumbfounded.

- Kim sent a letter in August 2019, inviting Trump to visit Pyongyang to hold the 4th summit. Trump was willing to do so by the end of the year.

${ }^{6}$ This paper is a revised and updated English version of "Dai-2-kai beicho-shunou-kaidan-go no Trump daitouryou kishakaiken ni miru media senryaku" written in Japanese, an article of the Journal of the School of Foreign Studies No. 522020 Language and Literature by Aichi Prefectural University, Japan. 
- Although the 4th summit was expected to be held in December 2019, this did not happen. North Korea said they would send a nice Christmas present to the US. The US believed that would be a long-range ballistic missile test. But North Korea did not act on that threat.

- In February 2020, Trump was acquitted at end of months-long impeachment process into allegations that he broke the law by pressuring Ukraine's leader to dig up damaging information on Joe Biden to take him on in the 2020 presidential election. He returned with absolute confidence. Trump delivered his 3rd State of Union Address in February 2020, highlighting a strong economy, Iran, and other issues. But he did not mention North Korea at all.

According to CNN reporters, Trump actually told advisors that he did not want another summit with North Korea's Kim before the election, and his reelection campaign team did not believe North Korea was an issue crucial to the President winning a return to office (Atwood \& Salama, 2020). He might think that he could easily be reelected, without a good result from the North Korea denuclearization deal.

\section{References}

Atwood, K., \& Salama, V. (2020). Trump tells advisers he doesn't want another summit with North Korea's Kim before the election. Retrieved from https://edition.cnn.com/2020/02/10/politics/trump-north-korea-thaw/index.html

Barber, S. (2019). Internal strife reported at Fox News caused by pro Trump propaganda. Retrieved from https://hillreporter.com/internal-strife-reported-at-fox-news-caused-by-pro-trump-propaganda-33605

Kuroi, B. (March 2, 2019). Kita-chousen wa 'himitsu no nuran-noushuku shisetsu' wo shishu shitaka-beichou shunou-kaidan 'goui nashi' de mieta ryoukoku no nerai (Did North Korea defend desperately their secret uranium enrichment facilities?-goals of the US and North Korea seen in no agreement at their failed summit). Tokyo: JBpress/isMedia. Retrieved from https://jbpress.ismedia.jp/articles/-/55648

Michael Cohen testimony: Trump responds during Vietnam news conference. (2019). Vox. Retrieved from https://www.vox.com/2019/2/28/18244483/trump-cohen-testimony-vietnam-news-conference-collusion

Michelson, M. (2003). Woman in the red dress' up front on war in Iraq famed political reporter Helen Thomas addresses audience in South Burlington. Retrieved from https://middleburycampus.com/16304/news/woman-in-the-red-dress-upfront-on-war-in-iraq-famed-political-reporter-helen-thomas-addresses-audience-in-south-burlington/

North Korea fires 2 projectiles in first test since latest talks stalled. (2019). Retrieved from https://www.nytimes. com/2019/10/31/world/asia/north-korea-missile.html\#: :text=\%E2\%80\%8BThe\%20projectiles $\% 20$ were $\% 20$ the, $2 \% 20$ into $\%$ 20waters $\% 20$ off $\% 20 J a p a n . \&$ text $=$ The $\% 20$ missile $\% 20$ launched $\% 20$ on $\% 20$ Oct,a $\% 20$ key $\% 20$ United $\% 20$ States $\% 20$ ally

Ott, L. B. (2019). Who's done more damage to America, Fox News of Twitter? Retrieved from https://www.newsweek.com/twitter-Fox-news-damage-american-democracy-1443088

Russo, A. (March 4, 2019). Trump played favorites with state-run media in Hanoi, CNN's Jim. HuffPost. Retrieved from https://www.huffpost.com/entry/donald-trump-hanoi-press-conference_n_5c7d0b5fe4b0614614dc9e

Sodekawa, H. (2018). The economist front covers: Effective communicators III. In MULBERRY British and American studies department journal 68th Issue (pp. 1-22). Aichi: Aichi Prefectural University.

Sodekawa, H. (2019a). Daitouryou wa by the way ga osuki (The president is fond of "by the way") (1). Tsuyaku buusu ha takara no yama (Interpreters' booth is a resource of treasures) 1st Issue. Japan Interpreters Organization's members only web magazine. Retrieved from https://www.japan-interpreters.org/news/info/

Sodekawa, H. (2019b). Daitouryou wa by the way ga osuki (The president is fond of "by the way") (2). Tsuyaku buusu ha takara no yama (Interpreters' booth is a resource of treasures) 2nd Issue. Japan Interpreters Organization's members only web magazine. Retrieved from https://www.japan-interpreters.org/news/info/

Sodekawa, H. (2019c). Genba taiou-ryoku wo migakou! Housou tsuuyakusha no nama-doutsuu skill (Respond to urgent needs on site! Broadcasting simultaneous interpreters' skills) (1). In Tsuyaku honyaku Jounal 2019 Spring (pp. 92-96). Tokyo: Ikaros Publishing Co.

Sodekawa, H. (2019d). Genba taiou-ryoku wo migakou! Housou tsuuyakusha no nama-doutsuu skill (Respond to urgent needs on site! Broadcasting simultaneous interpreters' skills) (2). Tsuyaku honyaku Jounal 2019 Autumn (pp. 104-108). Tokyo: Ikaros Publishing Co. 
Suzuki, A. (March 2, 2019). Haki-naki Trump-shi kaiken Asia-kei josei-kisha shimei-shita noha (Dispirited Mr. Trump's press conference-calling on Asian female reporters). Tokyo: Asahi Shimbun Digital. Retrieved from https://digital.asahi.com/articles/ASM313TW7M31UHBI01C.html

Wemple, E. (2019). Sean Hannity is the most influential TV host. Retrieved from https://www.washingtonpost.com/

Which way does your news lean? (2020). Retrieved from https://libguides.com.edu/c.php?g=649909\&p=4556556 